\title{
SPILLOVER EFFECTS OF INWARD FOREIGN DIRECT INVESTMENT ON LABOUR PRODUCTIVITY: AN ANALYSIS ON SKILL COMPOSITION IN MANUFACTURING INDUSTRY
}

\section{Norhanishah Mohamad Yunus ${ }^{1+}$ Tajul Ariffin Masron $^{2}$}

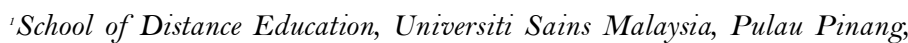 \\ Malaysia. \\ Email:norhanishah@usm.my Tel: +6046532303 \\ ${ }^{2}$ School of Management, Universiti Sains Malaysia, Minden Pulau Pinang, \\ Malaysia. \\ Email:tam@usm.my
}

(D) Check for updates

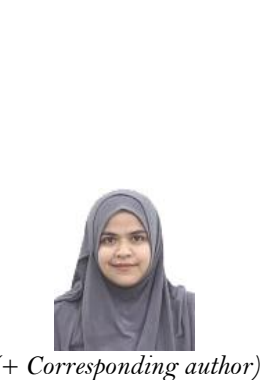

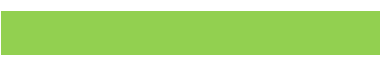

Article History

Received: 6 July 2020

Revised: 10 August 2020

Accepted: 14 September 2020

Published: 30 September 2020

\section{Keywords}

Spillover effects

Foreign direct investment

Skill composition

Labour productivity

Technology

Knowledge.

JEL Classification C33; D22; F36; F61.

\begin{abstract}
Using the current 2-digit levels of panel data set from 14 manufacturing industries during the period of 2000-2018, the present study adds to the literature by investigating both technology and knowledge effects from FDI spillovers on labour productivity according to skill composition. Applying the seemingly unrelated regression (SUR) estimator, the outcomes showed that the "technology effects" measured by the number of FDI companies are greater as compared to MNCS' capital investments and "knowledge" effects in increasing labour productivity. However, the diffusion of FDI knowledge via "learning effects" produced a significant negative relationship with labour productivity across all skill levels. Recognising that improvements in labour productivity are important to ensure that manufacturers remain competitive in line with industry 4.0 requirements, this study concluded that technology and knowledge from FDI spillovers can potentially increase labour productivity, but the success of transferring knowledge and technology depends on employee absorption capacities. Thus, this study highlights the need for employers to provide monetary incentive or personal awards to employees who are able to successfully transfer their FDI's knowledge and technology through the demonstration and competition effects to other employees.
\end{abstract}

Contribution/ Originality: This study contributes to the FDI spillover literature by comparing the weight of the effects of technology and knowledge transfers in increasing Malaysian labour productivity according to skill composition. The benefits of FDI spillovers on labour productivity, however, are rarely researched particularly in developing countries and at the industry level.

\section{INTRODUCTION}

One of the major challenges in the Malaysian labour market is the shortage of the necessary skills and knowledge to be productive in the fast-changing and increasingly competitive labour market (EPU, 2010). Despite the investment made in human capital and $\mathrm{R} \& \mathrm{D}$, these investments alone are insufficient to increase the number of skilled labour as well as to develop the quality of the workforce (EPU \& World Bank, 2007a). Malaysia has recognised that the process of skill upgrading and development of technology capacity can be integrated with foreign direct investment (FDI) because FDI spillover effects encompass both technology and knowledge. For 
Malaysia to forge ahead towards high value-added activities, it is essential to develop the capability to innovate, produce new technology, and design new products, through soft technology transfer, or knowledge transfer (EPU \& World Bank, 2007a; Yunus \& Wahob, 2019).

We are not refuting that Malaysia labour productivity growth of $3.5 \%$ for 2016 has shown an improvement as compared with $3.4 \%$ in 2015 but the performance is still considered unsatisfactory as the country's productivity level is still lagging behind other countries, such as Singapore and South Korea (Malaysia Productivity Corporation, 2017). In 2015, Singapore's labour productivity was almost two times higher than that of Malaysia, South Korea was 1.8 times higher, and Japan was 1.7 times higher. In ASEAN, Indonesia and the Philippines reported a growth of $4.6 \%$ and $4.4 \%$ respectively, despite a slowdown in global exports (Malaysia Productivity Corporation, 2017). At industry level, the data also show that the labour productivity in the E\&E equipment industry showed a decline in growth by $-9.75 \%$ between 2015 and 2016 and continued declining by $-7.67 \%$ between 2016 and 2017, even though the trend of FDI (measured by approved investment projects) in this industry increased by 2.68\% between 2016 and 2017 (MIDA, 2018). This declining pattern thus raises the question of the real benefits produced by technology spillovers that Malaysia is able to reap from the presence of FDI, as E\&E sector has a tremendous growth and it is dominated by leading MNCs with a few linkages to local firms.

A plethora of studies reiterates the importance of new knowledge transfer from foreign multinational corporations (MNC) in higher labour productivity and for sustaining competitive advantages, yet less attention is given to lower labour productivity issue from the presence of FDI especially in the developing country context (EPU \& World Bank, 2007a, 2007b, 2010; OECD, 2011). This is an important subject to be investigated to answer the unresolved issue of whether FDI spillover effects are only absorbed by Malaysian low-skilled workers, as the workers' activity in the Multinational Companies (MNCs) since the 1990s remained focused on assembly and test stages, which is the lower value-added part of the industry (OECD, 2011; Yunus, Said, \& Azman-Saini, 2015).

Considering the lack of research that measure directly both "technology" and "knowledge" effects of FDI spillover on labour productivity according to skill composition ${ }^{1}$ (Araújo, Bogliacino, \& Vivarelli, 2009) the present study thus aims to investigate the FDI spillover effects on labour productivity function. Most studies heavily emphasised on 'technology' effects rather than 'knowledge' effects originating from the presence of foreign technology on the host country (Araújo et al., 2009; Yunus et al., 2015). This study also focuses on separating the labour productivity function by skill composition in order to identify possible differences in relevant relationships, rather than only focusing on the relative effects as the capital and skill complementarities may be more obvious for skilled workers than for unskilled workers (Yunus et al., 2015). Little is known of how FDI spillovers affect the growth of unskilled workers (Araújo et al., 2009).

The remainder of the paper is organised as follows. Section 2 provides a review of the literature. In Section 3 , we detail the data description and scope of study. Section 4 then outlines the empirical model. Section 5 discusses the results. Finally, we close the paper with a conclusion and policy implications in Section 6.

\section{LITERATURE REVIEW}

The evolutionary theory discusses how the presence of MNCs affects the productivity spillovers in local firms. Theoretically, by introducing new technologies and products to domestic firms, the spillover effects of MNCs contributes to the initial knowledge. In line with the evolutionary theory, Blomström and Kokko (1998) outlined four ways in which FDI's technology and knowledge spillovers into local firms might influence the host country: (i) through the training effect that causes the movement of highly trained and skilled staff from foreign firms to domestic firms; (ii) through what is referred to as the "demonstration-imitation effect" that arises from arm's-length

\footnotetext{
1 The classification of skill composition according to Malaysia's job classification. We divided them into three categories, which are: high-skilled workers, mediumskilled workers, and low-skilled workers.
} 
relationships between MNCs and domestic firms, thus enabling the domestic firm to learn and adopt superior production technologies and managerial and organisational skills; (iii) through the "competition effect" from domestic firms when competition from MNCs forces domestic rivals to upgrade production technologies and techniques in order to remain productive and competitive, and (iv) through the "linkage effect", which is related to export spillovers by which the domestic firms can learn to export from the MNCs. This is a positive move, as it helps to improve the productivity and competitiveness of local firms, forcing them to operate efficiently by transforming the knowledge acquired into practical and commercial use, yet these gains cannot be internalised by these foreign firms (Lall, 1978). These results are known as spillover effects (Fan \& Warr, 2000). Meanwhile, the theory of Multinational Enterprises (MNEs) believes that MNEs act as an important source of technology transfer through foreign ownership, since one motive for FDI is to profit from utilising firm-specific, technology-intensive assets in many countries. The MNEs may affect the host countries through skill-biased technological change and relative demand for skilled labour.

The importance of FDI as a channel for skills upgrading toward higher productivity, particularly in developing countries, can be seen from the demand and supply perspectives. FDI may stimulate the demand for higher-skilled workers through technology transfer to the host-country affiliates; foreign ownership, technology flows and spillovers to market-mediated and host-country firms; as well as through investments in physical capital related to new techno (Blonigen \& Slaughter, 2001). On the supply side, the effect of spillovers via FDI may possibly induce a demand for skilled workers through investment in human capital in the short and long term. In the short term, MNCs interact with the host-country labour markets through on-the-job training and support for local educational institutions. In the long term, FDI collectively contributes to the overall macro environment through educational policies. Nevertheless, the method of inward FDI in influencing human capital development in particular, for skill upgrading on the supply side is much less clear, whether at the micro- or macro-levels (Slaughter, 2002). For instance, a study by Bruno, Crinò, and Falzoni (2012) showed that foreign capital contributed to the catching-up process and led to technological and organisational improvement, which fostered the restructuring process, thereby increasing both the demand and supply of skills. According to Buckley, Clegg, and Wang (2002) the technology spillovers via FDI is a principle source of positive spillovers for host countries, whether in developed or developing economies. Such advanced technology from FDI may spill over to domestic firms and improve the performance of the host country (Dunning \& Rugman, 1985).

Positive impact of foreign direct investment on the labour productivity of host industries is generally achieved through the establishment of technology, management skills and techniques, and capital and spillover effects on the local firms (Liu, Parker, Vaidya, \& Wei, 2001). Research on FDI spillover effects on labour productivity are, however, still absent from the empirical literature. This subject, thus, remains under scrutiny, particularly in developing countries and at industry level (Slaughter, 2002). Surprisingly, this issue garners very limited attention as most FDI studies focus on Total Factor Productivity and skilled labour demand (Driffield, Love, \& Taylor, 2009; Elia, Mariotti, \& Piscitello, 2009; Liu, Agbola, \& Dzator, 2016; Yunus et al., 2015). To the best of our knowledge, only a handful of recent studies investigated the direct impact of FDI on labour productivity, with studies in the context of developing countries remain limited.

For instance, Liu et al. (2001) reported that the presence of foreign firms in the 41 sub-sectors of the Chinese electronic industry enhanced labour productivity. The study reiterated that the benefits of FDI are dependent on the technological aptitude of the local firms, such that in order to receive more benefits from FDI, the domestic firms must possess greater technological abilities. Similar results of positive impact of FDI on labour productivity have also been reported in other studies (Blomström \& Persson, 1983; Blomström \& Wolff, 1994; Caves, 1971). Using data covering 41 developing countries for the time period of 2005 to 2008 to assess the extent to which technological spillovers from US influence labour productivity in the selected developing countries, Wang, Huang, and Chen (2012) found that the relationship between technological spillovers and labour productivity in developing 
countries are highly sensitive to model specification and estimation techniques. Simple pooled data estimations reveal a clear relation between technological spillovers and labour productivity while more complex models such as dynamic panel data models fail in this task. The result from their analysis shows that only import has a significant impact on labour productivity.

Mebratie and Bedi (2013) investigated the effect of the interaction between foreign firm ownership and black economic empowerment (BEE) on labour productivity using a two-period (2003 and 2007) firm level panel data from South Africa. This study concluded that regardless of the empirical specification, there were no spillover effects and no evidence that a greater degree of BEE compliance by foreign firms influenced labour productivity. In examining structural burden, Fagerberg (2000) suggests that higher education attainment increases labour productivity. Boghean and State (2015) investigated the connection between foreign direct investments and hourly productivity for the period of 2000-2012 in the European Union countries. After calculating the Spearman correlation coefficients, the coefficient values indicated that there was a direct and strong connection between the foreign direct investments inflows and average labour productivity in Bulgaria, Czech Republic, Germany, Estonia, Greece, Spain, Poland, Portugal, Slovenia and Slovakia. For Romania, the obtained Spearman coefficient proved that the connection was direct, strong and significant.

Since the 1980s, Malaysia has relied heavily on multinational companies (MNCs) not only for trade but also for investment, aid, and technology transfer (Ariff, Yokoyama, \& Kenkyūjo, 1992). According to Malaysian Investment Development Authority (MIDA), Japan ranked second in Malaysia's inward foreign direct investment (FDI) in 2013. Current data also indicate a strong tie between Japan and Malaysia in trade and investment. Despite the emerging importance of Japanese MNCs in the Malaysian economy, particularly in technology transfer, no comprehensive study has been done to analyse the spillover effects of MNCs on productivity or labour productivity in the Malaysian manufacturing sector especially at industry level. Only recently a study by Sulaiman, Azman, and Ismail (2016) investigated the impacts of globalisation, proxies by FDI, and the degree of openness of the economy and foreign labour, on the Malaysian services sector. The study employed random effects model and Generalized Method of Moments (GMM) dynamic panel model and both models yielded similar result showing that FDI positively impact and is significant in influencing labour productivity. The study thus recommends that FDI inflows should be increased, especially for large-scale investments with a relatively cheaper cost. This present study, hence, aims to look at the spillover effects of FDI, from the angles of technology and knowledge, on labour productivity by skill composition in the manufacturing industry.

\section{DATA DESCRIPTION AND SCOPE OF STUDY}

The main data sources in this study are gathered from the Department of Statistics Malaysia (DOSM) and Malaysian Industry and Development Authority (MIDA) based on a manufacturing survey on industries. The variables gathered from DOS are total employment, production and non-production workers, Research and Development (R\&D) investment, and cost of training (TRAIN). The data gathered from MIDA comprise three variables, namely the share of foreign capital investment (TECH), number of FDI companies (NF), and share of local employment working in the foreign manufacturing industry (EMP). The summary of statistics for the variables used in this study is shown in Appendix A.

Following Liu et al. (2001) the present study measures the labour productivity by value-added per worker to the number of average annual employees in each sub-sector of the manufacturing industry. The advantage of this measurement reflects the combined effects of changes in capital inputs, intermediate inputs, and overall productivity, without leaving out any direct effects of technical change, whether such effects are embodied or disembodied. We extend Liu et al. (2001) formula by categorising workers in each sub-sector of the manufacturing industries into non-production and production categories. Both non-production and production categories have their own high- and low-skilled workers. 
Based on the categorisation by Hollanders and Ter Weel (2002) non-production category consists of highskilled workers namely the legislators, senior officials and managers, professionals, technicians and associate professionals. Low-skilled workers include clerks, service workers, and shop and market sales workers. In the production category ${ }^{2}$, high-skilled workers comprise skilled agricultural and fishery workers, and craft and related trade workers. Low-skilled workers refer to the plant and machine operators and assemblers, and those in elementary occupations.

The classification of workers into production and non-production categories is more appropriate at the firm level data. There are several reasons to support this argument. Firstly, formal education or educational attainment is an imperfect measurement of skilled labour. Individuals with the same level of formal schooling show vastly different levels of skill in standardised tests. Educational attainment does not capture experience - it partially understates participation in further education and training, and there are variations in the quality of schooling over time and between regions/countries (Leamer, 1994). Secondly, employers may not be employing highly educated workers for skill-demanding jobs (Chennells \& Van Reenen, 1999).

Technology spillover effects of FDI are measured by foreign capital investment (TECH) as a channel of spillover effects through "technology" (Bandick \& Hansson, 2009; Bwalya, 2006). In this study, foreign capital investment is defined as a share of foreign capital investment from total foreign investment in a year. Another proxy used to measure technology spillover of FDI is the number of FDI company establishments in the manufacturing sector (NF). NF acts as a proxy for ease of access to technology (Badriah, Alisjahbana, Wibowo, \& Hadiyanto, 2019).

Meanwhile, the knowledge effects (EMP) from FDI spillovers are measured as a share of local employment working in the foreign firms to total employment (parents and affiliates) in each manufacturing industry as a proxy for ease of access to FDI's knowledge (Blonigen \& Slaughter, 2001; Girma, Greenaway, \& Wakelin, 2001). The quadratic effects $\left(\mathrm{EMP}^{2}\right)$ techniques as applied by Figini and Görg (1999) and Taylor and Driffield (2005) need to be included so as to examine whether FDI facilitates technological change and allows workers to assimilate knowledge over time through "learning effect".

The control variables used in this study are human capital, R\&D investment, and domestic investment from local investors. Human capital is a proxy by training investment. Training refers to the cost of training sponsored by the industry. A few studies explored the effect of training sponsored by firms (Ballot, Fakhfakh, \& Taymaz, 2001; Yunus, Said, \& Hook, 2014; Yunus \& Wahob, 2019). In this study, cost of training is calculated as an aggregate and includes in-house training and on-the-job training. The cost of training also includes the training of all workers because of the non-availability of data disaggregating training costs according to forms of training, job classification, and skills group. We choose the combination of human capital and R\&D investments, domestic investment from local investors, and firm size as control variables. In fact, the relevant empirical literature on the impact of investments in human capital and $\mathrm{R} \& \mathrm{D}$ on labour productivity is still in its infancy despite some empirical studies highlighting the complementarities between both investments (Ballot et al., 2001; Yunus \& Hamid, 2017; Yunus, Said, \& Hook, 2014).

This study focuses on 14 manufacturing industries at 2-digit level and aggregate level because technology spillovers have been associated with the manufacturing sector for a long time. These industries are Electronics and Electrical (E\&E), Food and Beverage, Textiles, Leather, Wood, Chemical, Rubber, Plastic, Basic Metal, Machinery and Equipment, Transport Equipment, Non-Metallic Mineral, Publishing, and Paper and Printing. These

\footnotetext{
${ }^{2}$ In the case of Malaysia, there is no panel data provided by DOS at industry level in the manufacturing sector for skilled agricultural and fishery workers, and craft and related trade workers. This is similar to low-skilled workers in non-production category (except for clerical).
} 
industries are supported by private investment, and the regulatory framework is changed to attract both domestic and foreign investments, thus potentially contributing to economic growth and labour productivity (EPU, 2016).

The present study examines the period of 2000-2018. The limitation on the temporal scope of the present study is due to the industrial classification system (previously known as the Malaysia Industrial Classification (MIC), 1972: revised in 1979). After 2008, the MSIC code was revamped by DOS. The amount of FDI inwards to Malaysia manufacturing industries increased dramatically during the period of 2000-2018; in line with our aim to study whether and how inward spillover effects of FDI by major investor countries do influence the growth rate of skilled and low-skilled workers. During this period, the number of local employments who worked in the MNCs company has increased, hence enabling us to measure whether Malaysian workers can assimilate the knowledge effect from MNCs and that the fast pace is contributes towards higher labour productivity (Yunus, 2014).

\section{EMPIRICAL MODEL}

This section presents the empirical methodology used to investigate spillover effects of FDI alongside other possible explanatory variables effect on labour productivity. The combination of model specification by Liu et al. (2001); Bronzini and Piselli (2009) and Ballot et al. (2001) are used to examine the FDI spillover effects and other variables factors that influence labour productivity. The basic model for labour productivity of skilled Equation 1, medium Equation 2 and low-skilled Equation 3 respectively can be expressed as follows:

$$
\ln H S_{i t}=\ln A_{i t}+B_{1} \ln \left(\frac{K}{L}\right)_{i t}+B_{2} \ln F D I_{i t}+B_{3} \ln N_{i t}+B_{4} \ln E M P_{i t j}+B_{5} \ln E M P_{i j t}^{2}+B_{6} \ln X_{i t}+\varepsilon_{i t}
$$

$$
\ln M S_{i t}=\ln A_{i t}+B_{1} \ln \left(\frac{K}{L}\right)_{i t}+B_{2} \ln F D I_{i t}+B_{3} \ln N_{i t}+B_{4} \ln E M P_{i t j}+B_{5} \ln E M P_{i j t}^{2}+B_{6} \ln X_{i t}+\varepsilon_{i t}
$$

$$
\ln L S_{i t=} \ln A_{i t}+B_{1} \ln \left(\frac{K}{L}\right)_{i t}+B_{2} \ln F D I_{i t}+B_{3} \ln N_{i t}+B_{4} \ln E M P_{i t j}+B_{5} \ln E M P_{i j t}^{2}+B_{6} \ln X_{i t}+\varepsilon_{i t}
$$

where $i$ and $t$ are the industry and time index respectively. $Y$ refers to labour productivity per value-added for highskilled $(H S)$, medium-skilled $(M S)$ and low-skilled $(L S)$ workers respectively. $\frac{K}{L}$ ratio of capital to worker (K/L) or capital intensity is approximated by gross investments in fixed capital per worker (Corvers, 1997). FDI and $N$ are share of foreign capital investment from total investment and the number of foreign companies in the manufacturing industry respectively to represent FDI spillovers via "technology effects". EMP is the share of local employment in foreign firms to total employment (parents and affiliates) that is used as a proxy for FDI spillovers via "learning effect". $E M P S^{2}$ is the quadratic effects utilised to examine whether foreign firms facilitate technological change and allow skilled workers to assimilate knowledge over time through "learning effect". X represents other factors commonly considered in discussing labour productivity, namely TRAIN (cost of training per employee), $R D$ (R\&D investment), $D S$ (share of domestic investment from local investors), and $F S$ (firm size). $\varepsilon_{i t}$ is an error term that captures the time varying firm specific productivity shocks. 
With the limitation in panel data at 2-digit industry level (in our case we have 266 observations), we employ a seemingly unrelated regression (SUR) estimator, which is one of the panel data estimation methods (Zellner, 1962; Zellner, 1963). ${ }^{3}$ In our case, SUR is the best method of estimating panel data models as the number of industry (N) $=14$ industries are long than year $(T)=19$. When estimating the SUR model, the data need to be arranged as a time series (not a panel) with different variables listed separately. In the basic SUR model, the errors are assumed to be homoscedastic and linearly independent within each equation. By applying this method, the outcome of this analysis is perhaps useful in providing a preliminary picture of the levels of Malaysian skills required to absorb the spillover effects of FDI. We can then identify which spillover effects of FDI have more influence on the Malaysian labour productivity by taking account of the error terms' correlations across equations leads to better predictions of future values of the dependent variables. The SUR estimator provides the lowest standard errors of the estimated parameters and thus, the highest precision of the estimates.

The present study also conducts a multicollinearity test to get more certainty. Using panel data is one way to overcome multicollinearity because the number of observations become larger. The results of multicollinearity test use the correlation matrix between the independent variables as shown in Appendix B. The results show the correlation value for all variables is less than 0.8 , indicating that there is no multicollinearity in the research model (Gujarati \& Porter, 2012). Also, multicollinearity does not appear to be a serious concern since the VIFs for these variables are below 3.0 (Hair, Joseph, Rolph, Ronald, \& William, 1995).

The regression result of productivity on high-, medium- and low-skilled labour model will be analysed. For the sake of robustness, this study estimates the effects of FDI spillover through "technology" and "knowledge" separately in model (1) and model (2) and later in model (3), both variables of "technology" and "knowledge" are estimated simultaneously in the labour productivity function.

This is in line with the motivation of this study to examine which spillover effects are more assimilated and absorbed by high-, medium- and low-skilled workers, and how these effects contribute to higher labour productivity. The third model re-estimates the previous model by including both FDI spillovers variables via technology and knowledge effects into labour productivity model.

\section{RESULT AND DISCUSSION}

In this section, we begin the estimated results of high-skilled labour's productivity as an outcome of technology spillover effects from FDI in the 14 Malaysian manufacturing industries as shown in Table 1. In Model (1), the overall results reveal that all the variables used to influence the productivity of high-skilled workers are reported positive and statistically significant. Regarding the spillover effects of FDI, this study shows that the "technology" effects measured by the number of FDI companies in the Malaysian manufacturing industry and foreign capital investment are significant at $\alpha=1 \%$ with a value of 0.581 and 0.081 respectively. It means that the capital investment from FDI facilitate firm's access to FDI technology and, along with the increasing number of FDI companies, has a positive effect on the labour productivity growth of high-skilled labour in the Malaysian manufacturing industry.

\footnotetext{
${ }^{3}$ It is important to note that, before we select SUR as a best method to analyse the results in this study, several model selection tests were tested such as Ordinary Least Square (OLS), Generalized Method of Moments (GMM), Random Effect and Fixed Effect Model but we could not yield the best results. It is well-known that ordinary least squares which ignore the correlation patterns across blocks may yield inefficient estimators. For GMM, the condition to perform GMM is that the number of observations (N) must be greater than $T$. For Random Effect estimator, we cannot establish small sample properties. For fixed-effects models, even though it is widely recognised as the convenient and powerful tools for longitudinal data analysis, there are limitations in these models. The primary limitation is unobserved heterogeneity due to unmeasured characteristics that do vary over time. The problem is that fixed-effects coefficients are biased in a conservative fashion when the data are characterised by a small number of panels (Allison, 2009). In our case, we also found standard errors for fixed effects coefficients are often larger than those for other methods, especially when the predictor variable has little variation over time.
} 
In Model (2), by including "knowledge" effects of FDI variables into the model, the result, as presented in Table 1, is similar to the result obtained using Model (1). All of the variables significantly produce positive effects in increasing high-skilled labour's productivity ${ }^{4}$. The knowledge transfer from FDI inflows shows a positive significant at $\alpha=1 \%$ with a value of 0.629 .

In Model (3), we re-estimate the previous model by incorporating FDI spillover effects from both "technology" and "knowledge" into the model. The result confirms that local R\&D variables are significant in influencing highskilled labour's productivity as compared in model (2) without "technology" effects brought from FDI. This finding reiterates previous research that found a positive correlation between FDI inflows and local R\&D (Blomström \& Kokko, 1998; Yunus et al., 2015). Thus, the FDI spillover from both technology and knowledge effects to Malaysian manufacturing industries are larger and FDI also tends to influence the overall or other spillovers compared to inclusion of spillover effects of knowledge alone in the model. The FDI inflows increase local innovation in Malaysian manufacturing through reverse engineering and soft-technology transfer that embodied knowledge and modern technology (Lee, Mohayiddin, \& Kanesan, 2011; Yunus \& Wahob, 2019).

Table-1. Regression results for high-skilled labour productivity, 2000-2018.

\begin{tabular}{|c|c|c|c|c|c|c|}
\hline \multirow{2}{*}{ Variables } & \multicolumn{2}{|c|}{ Model (1) } & \multicolumn{2}{|c|}{ Model (2) } & \multicolumn{2}{|c|}{ Model (3) } \\
\hline & COEFF & S.E & COEFF & S.E & COEFF & S.E \\
\hline \multicolumn{7}{|l|}{$\begin{array}{l}\text { Dependant Variable: Skilled Labour } \\
\text { s Productivity }\end{array}$} \\
\hline Capital/ Labour ratio & 0.087 & $(0.011)^{* * * *}$ & 0.059 & $(0.013)^{* * * *}$ & 0.065 & $(0.010)^{* * * *}$ \\
\hline \multicolumn{7}{|l|}{ Technology Spillover Effects } \\
\hline $\begin{array}{l}\text { Share of Foreign } \\
\text { Investment }(F D I)\end{array}$ & 0.081 & $(0.029)^{* * * *}$ & - & - & 0.053 & $(0.026)^{* * * *}$ \\
\hline Number of Foreign Company $(N)$ & 0.581 & $(0.026)^{* * * *}$ & _- & _- & 0.407 & $(0.030)^{*}$ \\
\hline \multicolumn{7}{|l|}{ Knowledge Spillover Effects } \\
\hline $\begin{array}{l}\text { Share of Local Employment in } \\
\text { Foreign Firms }(E M P)\end{array}$ & - & - & 0.629 & $(0.065)^{* * *}$ & 0.364 & $(0.005)^{* * * *}$ \\
\hline Learning Effects $\left(E M P^{2}\right)$ & _- & _- & -0.058 & $(0.014)^{* * * *}$ & -0.043 & $(0.011)^{* * * *}$ \\
\hline \multicolumn{7}{|l|}{ Control Variables } \\
\hline Training Investment (TRAIN) & 0.06 & $(0.022)^{* * * *}$ & 0.121 & $(0.024)^{* * * *}$ & 0.047 & $(0.019)^{* * * *}$ \\
\hline R\&D Investment $(R D)$ & 0.049 & $(0.012)^{* * *}$ & 0.015 & -0.014 & 0.021 & $(0.011)^{*}$ \\
\hline $\begin{array}{l}\text { Share of Domestic } \text { Direct } \\
\text { Investment }(D I)\end{array}$ & 0.124 & $(0.027)^{* * * *}$ & 0.145 & $(0.021)^{* * * *}$ & 0.137 & $(0.024) * *$ \\
\hline Firm Size $(F S)$ & 0.198 & $0.002)^{* * * *}$ & 0.153 & $(0.023)^{* * * *}$ & 0.253 & $(0.019)^{* * * *}$ \\
\hline R-squared & \multicolumn{2}{|c|}{0.891} & \multicolumn{2}{|c|}{0.857} & \multicolumn{2}{|c|}{0.919} \\
\hline No. of Observation & \multicolumn{2}{|c|}{266} & \multicolumn{2}{|c|}{266} & \multicolumn{2}{|c|}{266} \\
\hline
\end{tabular}

COEFF: Coefficient, SE: Standard error. ${ }^{*} \mathrm{p}<0.05 ;{ }^{* *} \mathrm{p}<0.1 * * * \mathrm{p}<0.001$.

The positive findings concerning spillover effects of FDI on high-skilled labour productivity can be attributed to the capacity of high-skilled workers to absorb both technology and knowledge transfers from FDI.

This capacity then translates into higher productivity, as revealed in this study. The Malaysian government's effort, via Technology Park Centre that organised various training programmes, may have improved the capacity of

\footnotetext{
${ }^{4}$ Knowledge transfer mechanisms include personnel movement, guided learning-by-doing, learning by observation, in-house or off-house training, replication and innovative activities, scientific publications and presentations, interaction among employees (team work), working with experts/expatriates and coaches/mentors, alliances and inter-organisation relationships (Kao, Kao, and Mazzuchi (2006); Foss and Pedersen (2002).
} 
skilled-workers to adapt to foreign technology 5 (Awang, Hussain, \& Malek, 2009b). Consistent results in this study also supported that employer's investment in their workers training contributes to higher productivity of highskilled workers in all models.

An interesting observation in Model (2) and Model (3) centres on a significant negative correlation between knowledge spillovers of FDI and high-skilled labour's productivity as indicated by $E M P^{2}$. The results suggest that the knowledge transfers from FDI inflows through the "learning" effect appear to be assimilated minimally by highskilled workers in the Malaysian manufacturing industry despite its coefficient being only 0.043 less than technology effects (with coefficient of 0.407). Previous literature similarly reported that the negative effects of FDI on local firms could be due to negative competition effect from multinationals outside the region or country, which is not offset by positive spillovers, which appear to be more prevalent at the local level (Girma \& Görg, 2005). While this explanation seems appealing, it is, however, not possible to determine the reasons for such negative spillover effects from FDI outside the country with our data.

In the case of FDI spillover effects on medium-skilled labour productivity, the overall results in Table 2 suggest that both technology and knowledge effects are significant in the workers productivity in all models. The results in Model (2) show that by including FDI "knowledge" spillover variable, the effects of training investment made by manufacturing firms become significant and influence the medium-skilled labour' productivity as compared to Models (1) and (3). The result in Model (2) proves that the skill upgrading of medium-skilled labour can increase by $63.0 \%$ from knowledge spillovers from FDI.

Table-2. Regression Results for Medium-Skilled Labour Productivity, 2000-2018

\begin{tabular}{|c|c|c|c|c|c|c|}
\hline \multirow{2}{*}{ Variables } & \multicolumn{2}{|c|}{ Model (1) } & \multicolumn{2}{|c|}{ Model (2) } & \multicolumn{2}{|c|}{ Model (3) } \\
\hline & COEFF & S.E & COEFF & S.E & COEFF & S.E \\
\hline \multicolumn{7}{|l|}{$\begin{array}{l}\text { Dependant } \\
\text { Medium-Skilled Labour 's } \\
\text { Productivity }\end{array}$} \\
\hline Capital/ Labour ratio & 0.261 & $(0.024) * * *$ & 0.235 & $(0.027)^{* * *}$ & 0.216 & $(0.022)^{* * * *}$ \\
\hline \multicolumn{7}{|l|}{ Technology Spillover Effects } \\
\hline $\begin{array}{l}\text { Share of Foreign Capital } \\
\text { Investment }(F D I)\end{array}$ & -0.099 & $(0.022)^{* * *}$ & - & - & -0.180 & $(0.037)^{* * * *}$ \\
\hline $\begin{array}{l}\text { Number of } \quad \text { Foreign } \\
\text { Company }(N)\end{array}$ & 0.688 & $(0.056)^{* * * *}$ & - & - & 0.364 & $(0.066)^{* * * *}$ \\
\hline \multicolumn{7}{|l|}{ Knowledge Spillover Effects } \\
\hline $\begin{array}{l}\text { Share of } \\
\text { Employment in } \\
\text { Firms }(E M P)\end{array}$ & - & - & 0.630 & $(0.056)^{* * *}$ & 0.793 & $(0.044)^{* * * *}$ \\
\hline Learning Effects $\left(E M P^{2}\right)$ & - & - & -0.233 & $(0.030)^{* * *}$ & -0.197 & $(0.023)^{* * * *}$ \\
\hline \multicolumn{7}{|l|}{ Control Variables } \\
\hline $\begin{array}{ll}\text { Training } & \text { Investment } \\
(T R A I N) & \end{array}$ & 0.070 & 0.074 & 0.214 & $(0.051)^{* * *}$ & 0.068 & $(0.042)$ \\
\hline R\&D Investment $(R D)$ & 0.137 & $(0.025)^{* * * *}$ & 0.139 & $(0.139)^{* * * *}$ & 0.142 & $(0.023)^{* * * *}$ \\
\hline $\begin{array}{l}\text { Share of Domestic Direct } \\
\text { Investment }(D I)\end{array}$ & 0.004 & $(0.003)$ & -0.058 & $(0.029)^{* * *}$ & 0.078 & $(0.038)^{*}$ \\
\hline Firm Size & 0.187 & $(0.045)^{* * * *}$ & 0.076 & $(0.049)$ & 0.283 & $(0.042)^{* * * *}$ \\
\hline R-squared & \multicolumn{2}{|c|}{0.800} & \multicolumn{3}{|c|}{0.758} & 0.851 \\
\hline No. of Observation & \multicolumn{2}{|c|}{266} & \multicolumn{3}{|c|}{266} & 266 \\
\hline
\end{tabular}

Note: All variables are transformed into natural log. Standard errors are in parentheses. COEFF: Coefficient, SE: Standard error. ${ }^{*} \mathrm{p}<0.05$; ${ }^{* *} \mathrm{p}<0.1{ }^{* * *} \mathrm{p}<0.001$.

\footnotetext{
${ }_{5}$ The training programmes include the fields of robotics and flexible manufacturing systems, and provide specialised engineering services in laboratories, the precision machining center, rapid prototyping center, plastic injection molding center, and metal stamping center.
} 
As such, local firms should be encouraged to invest in training programmes so as to ensure workers are able to ease into accessing FDI's knowledge. Depending on the industry, it is generally important for production clerks to have excellent communication skills, as they are the first point of reference for other professionals looking for information and instruction specific to the company. For example, clerks employed in a manufacturing company might assist in filling work orders or stamping envelopes for mass mailings.

As shown in Table 2, FDI technology spillover via foreign capital investment is statistically significant. However, there is a negative relationship between the technology spillover and its influence on the productivity of medium-skilled labour, as indicated in Model (1) and Model (3).

This finding implies that the technology spillover of FDI inflows are more focused on the production process ${ }^{6}$ that may not appeal to medium-skilled workers as compared to "knowledge" spillovers. Thus, less focus is given in providing training investment to medium-skilled workers related to technological improvement. The findings of this study, as shown in both Models (1) and (3) in Table 2, reflect the current situation where the government has approved a number of projects with a Customised Incentive Scheme to implement training programmes for Malaysians in the field of product/process technology. These programmes aim to enhance the creation of knowledge-based workforce and improve technical skills among Malaysian workers under the Economic Transformation Programme (EPU, 2010, 2016).

For low-skilled labour, the results as shown in Table 3 are similar to the findings concerning high- and medium-skilled workers. Both knowledge and technology effects of FDI spillovers are statistically significant in influencing low-skilled labour productivity. However, the econometric estimation results revealed that the coefficient of capital labour ratio, local R\&D investment and domestic direct investment from domestic investors are significantly negative in both Models (1) and (3). This negative correlation thus indicates that if these variables in the manufacturing sector in the beginning to the end of the period increases by an average of $1 \%$, ceteris paribus, then the low-skilled labour productivity growth of the sector will decrease by the coefficient value. Consequently, factors contributing to the acceleration of productivity growth in the manufacturing sector have a negative effect on labour productivity growth. In other words, the ability of the manufacturing sector to increase the productivity of low-skilled labour has decreased.

Meanwhile, the local $\mathrm{R} \& \mathrm{D}$ investment was found to be statistically insignificant in influencing the low-skilled productivity. This finding suggests that there are structural patterns in the manufacturing firms where the firm moves from low production activity to high value-added production. There is, therefore, a tendency for a reallocation of labour among the sectors in Malaysia, particularly where low-skilled labour shifts from the high productivity sector to the low one based on their capacity to access the technology spillovers of FDI. Similarly, McMillan and Rodrik (2011) agreed that growth can also be driven by a reallocation of workers from low productivity sectors to higher productivity sectors. The reallocation of workers based on their capacity may lead to high productivity due to job satisfaction. Most current empirical studies assert that there is a positive relationship between job satisfaction and productivity (Bhatti \& Qureshi, 2007; Böckerman, Ilmakunnas, \& Johansson, 2011; Hoboubi, Choobineh, Ghanavati, Keshavarzi, \& Hosseini, 2017; Yunus, 2018). Job satisfaction is not only a determining factor in occupational choice but may also contribute to a firm's competitiveness, productivity, and growth potential (Millán, Hessels, Thurik, \& Aguado, 2013).

${ }^{6}$ Production process can act as a channel for technology spillovers (Jaguli, Malek, \& Palil, 2014). 
Table-3. Regression results for low-skilled labour productivity, 2000-2018.

\begin{tabular}{|c|c|c|c|c|c|c|}
\hline \multirow{2}{*}{ Variables } & \multicolumn{2}{|c|}{ Model (1) } & \multicolumn{2}{|c|}{ Model (2) } & \multicolumn{2}{|c|}{ Model (3) } \\
\hline & COEFF & S.E & COEFF & S.E & COEFF & S.E \\
\hline \multicolumn{7}{|l|}{$\begin{array}{l}\text { Dependant } \begin{array}{l}\text { Variable: } \\
\text { Low Skilled Labour 's } \\
\text { Productivity }\end{array} \\
\end{array}$} \\
\hline Capital/ Labour ratio & -0.257 & $(0.034) * * *$ & -0.205 & $(0.033)^{* * * *}$ & -0.186 & $(0.032)^{* * * *}$ \\
\hline \multicolumn{7}{|l|}{$\begin{array}{l}\text { Technology Spillover } \\
\text { Effects }\end{array}$} \\
\hline $\begin{array}{lrr}\begin{array}{l}\text { Share } \\
\text { Capital } \\
(\text { FDI })\end{array} & \begin{array}{r}\text { Foreign } \\
\text { Investment }\end{array} \\
\end{array}$ & 0.164 & $(0.057)^{* *}$ & - & - & 0.209 & $(0.055)^{* * * *}$ \\
\hline $\begin{array}{l}\text { Number of Foreign } \\
\text { Company }(\mathrm{N})\end{array}$ & 0.032 & $(0.087)$ & - & - & 0.278 & $(0.097)^{*}$ \\
\hline \multicolumn{7}{|l|}{$\begin{array}{l}\text { Knowledge Spillover } \\
\text { Effects }\end{array}$} \\
\hline 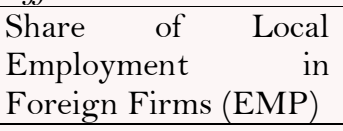 & - & - & -0.394 & $(0.056)^{* * *}$ & -0.192 & $(0.047)^{* * * *}$ \\
\hline $\begin{array}{l}\text { Learning } \quad \text { Effects } \\
\left(\mathrm{EMP}^{2}\right)\end{array}$ & - & - & -0.230 & $(0.035)^{* * * *}$ & -0.226 & $(0.035)^{* * * *}$ \\
\hline \multicolumn{7}{|c|}{ Control Variables } \\
\hline $\begin{array}{ll}\text { Training } & \text { Investment } \\
\text { (TRAIN) } & \\
\end{array}$ & 0.194 & $(0.068)^{* *}$ & 0.250 & $(0.060)^{* * * *}$ & 0.215 & $(0.061)^{* *}$ \\
\hline R\&D Investment (RD) & -0.080 & $(0.036)$ & -0.043 & $(0.035)$ & -0.038 & $(0.032)$ \\
\hline $\begin{array}{l}\text { Share of Domestic } \\
\text { Direct Investment }\end{array}$ & -0.125 & $(0.059)^{*}$ & 0.017 & $(0.035)$ & -0.152 & $(0.055)^{* *}$ \\
\hline Firm Size & 0.696 & $(0.064)^{* * *}$ & 0.483 & $(0.058)^{* * * *}$ & 0.522 & $(0.062)^{* * * *}$ \\
\hline R-squared & \multicolumn{2}{|c|}{0.817} & \multicolumn{2}{|c|}{0.723} & \multicolumn{2}{|c|}{0.765} \\
\hline No. of Observation & \multicolumn{2}{|c|}{266} & \multicolumn{2}{|c|}{266} & \multicolumn{2}{|c|}{266} \\
\hline
\end{tabular}

Next, we look at the positive and significant effects of technology on low-skilled labour productivity. This study shows that both the "technology" effects measured by the number of FDI companies in the Malaysian manufacturing industry and foreign capital investment are significant at $\alpha=1 \%$, with values of 0.278 and 0.209 respectively as shown in Model (3). A possible explanation for this result is that the high level of FDI enjoyed by Malaysia has been associated with intermediate capital investment rather than high value production. As a result, the overall impact of capital investment is biased against unskilled labour as opposed to the skilled ones. This statement is supported by the results of the study, which also show that a $1 \%$ increase in foreign capital investment enhances the productivity of low-skilled workers by $20.9 \%$, as compared to $5.3 \%$ for high-skilled workers as shown in Table 1. In the case of Malaysia, there are still many unskilled workers at various levels of production and the local firm's low absorption capacity limits the ability of workers to absorb and apply technology investments brought by MNCs to local firms, which include technological knowledge. Consequently, this becomes a major obstacle in the rapid growth of labour productivity (Yunus et al., 2015).

\section{CONCLUSION AND POLICY IMPLICATIONS}

This study goes beyond the existing research in the area of FDI spillovers by examining Multinational Corporations' technology and knowledge spillover effects in Malaysia. Specifically, this study attempts to contribute to the FDI spillover literature by comparing the influence of technology effects with knowledge effects in labour productivity according to skill composition in the Malaysian manufacturing industries. This paper provides 
additional evidence on the spillover effects of FDI from both channels of "technology" and "knowledge" influencing labour productivity according to skill composition in the Malaysian manufacturing industries.

Based on the estimation of labour productivity function for high-, medium- and low-skilled workers on 14 manufacturing industries during the period of 2000-2018, at a glance, the econometrics results revealed that all the factors that determine the Malaysian labour productivity - investments in training, local R\&D, domestic investment from local investors, firm size and both FDI spillover effects from "technology" and "knowledge" significantly contribute to the increase of Malaysian labour productivity.

This study also highlighted that the productivity of Malaysian workers across all skill levels benefits from FDI's knowledge and technology diffusions. These benefits may be embodied in various forms such as product, process or management technical knowledge, process knowledge, production facilities, and financial and market knowledge (Awang, Hussain, \& Malek, 2009a; Jaguli et al., 2014).

Another notable finding pointed to the strong association between FDI spillover effects of "technology" and "knowledge" and local R\&D investment in increasing the level of productivity of high-skilled workers. The local R\&D became significant in influencing the high-skilled labour's productivity as compared with the without "technology" effects brought from FDI, hence suggesting that innovation and technology transfer of FDI through production technology helped improve local suppliers' production and technology. This transfer of knowledge and technology supports Malaysia's aim to move forward from manufacturing to R\&D operations (Malaysia Investment Development Authority, 2018).

The results in this study also prove that FDI spillover effects are more influential in increasing labour productivity than domestic investment from local investors and R\&D investment. This finding is consistent with the result from studies by Coe and Helpman (1995); Keller (1998) and Frantzen (2000). In this regard, the inflows of FDI should be encouraged so as to increase the Malaysian labour productivity via R\&D activities. This is because local $\mathrm{R} \& \mathrm{D}$ activities conducted by Malaysian enterprises are domestic market-oriented and deal with relatively low-level technologies, thus creating a demand only for semi- and low-skilled workers. This becomes the main hindrance to absorb the high-impact technology from FDI and thus lowering the productivity level of skilled labour.

This study also proposes that the policy makers revive the role of Technology Park Malaysia (TPM) as an instrument to promote innovation globally, considering that technology parks are the most popular instruments for the development of high technology in many countries. TPM must be able to link up with internationallyrecognised institutions and industry.

In a similar fashion, the productivity of medium-skilled workers can be increased by $6.8 \%$ via skill upgrading training due to the presence of FDI that brought both technology and knowledge into industries. The employers, therefore, may feel compelled to invest in the training programmes so as to ensure their workers are able to access and adopt the management and knowledge effects of FDI.

Based on the estimation results for low-skilled workers, there is a need for a long-term policy to encourage the FDI inflows into low receiving industries that employed mainly low-skilled workers. The activities of MNCs involving low-receiving industries must be regulated to ensure that these activities are not confined to low-level production activities such as assembly \& test activities. Instead, it is imperative to upgrade to higher-level activities with the prospect of acquiring modern technology. This technology can be interpreted broadly to include product, process, and distribution technology, as well as management and marketing skills. Therefore, financial support from government for good quality and appropriate education and general training for low-skilled workers is required to make FDI work for the development of workers across all skill levels.

A comparison made between the "technology" and "knowledge' effects of FDI spillovers on labour productivity found that there is no significant difference on how these effects influence the three types of labour skills in the manufacturing industry. However, when compared with capital investment from foreign investors and FDI 
spillover effects via knowledge channel, the spillover effects of technology greatly impact labour productivity, as indicated by the number of FDI companies in the manufacturing industry. The productivity of high-, medium- and low-skilled workers could be increased by $40.7 \%, 36.4$ and $27.8 \%$ respectively as a result of the establishment of FDI companies in the manufacturing industry. These results indicate that Malaysian workers may have the ability to adopt and imitate the technology effects by FDI companies but the level of absorptive capacity for all types of labour skills could not be determined yet in our data.

The findings of this study also suggest that the presence of MNCs in the Malaysian manufacturing industry may increase skill-biased technological change towards higher productivity through the "competition effects" and "demonstration-imitation effects". The competition effects from MNCs force domestic firms to upgrade production technologies and techniques to remain productive and competitive. This is a positive move, as it helps to improve the labour productivity and competitiveness of local firms, forcing labour to operate efficiently by transforming the knowledge acquired into practical and commercial use (Lall, 1978). As such, the competition among local expertise in the manufacturing firms contributes to the foreign MNCs by generating a new technology in terms of input, products, and process development.

Meanwhile, the presence of multinationals via "demonstration effects" together with their new products and advanced technologies may thereby encourage domestic firms to imitate and innovate. The superior knowledge brought into the economy through FDI may lead domestic firms to improve through worker movement and imitation. If domestic firms learn better technology from MNCs, then this may also lead to more local innovation activity.

Based on the coefficient values obtained in investigating the "knowledge" effects of FDI inflows into the manufacturing industries, it can be concluded that there is a required minimum value of labour capacity to absorb and respond positively between knowledge inflows from FDI and knowledge creation via imitation process. A successful absorption of knowledge eventually results in higher labour productivity.

Nonetheless, the overall results reported that the "learning" effects as indicated by $E M P^{2}$ showed a negative relationship with labour productivity for all three levels of labour skills. A study by Giroud and Mirza (2006) revealed that the adaptive knowledge is more difficult than the production systems. This study suggests that the negative relationship may be due to the inability of our industries to adapt and learn to the technological advancements dished out by the foreign firms. Similarly, a study by Awang et al. (2009b) found that the success in knowledge transfer depends on employee absorption capacities, organisational learning climate, and the willingness of foreign expatriates in MNCs to transfer knowledge.

As highlighted in this study, workers' absorption capacity of foreign technological developments determines the level of productivity growth that can be achieved. Therefore, it is fundamental to provide workers with the proper education and training so that they are equipped with the skills required to make this absorption happen. The present study suggests that education and training should be complementary to the technological change to solve for the available skill that is no longer required by firms as well as the short fall in the skills available for workers (Yunus, 2017; Yunus \& Hamid, 2017; Yunus, 2018). Apart from that, there needs to be a co-operation between universities and industries so as to ensure that the transfer of commercial knowledge from universities to practitioners or transfer of technology-universities (UITT) can be made through licensing agreements, research collaborations.

This study suggests that the "learning" effect from FDI spillovers can be improved further when MNCs provide training for employees and hands-on learning opportunities, and international trips, which enable a better communication between the persons involved in the project; thus increasing labour productivity of skilled workers. As the technology parks are the most popular instruments for high technology development in many countries, the policy makers may need to look into reviving the role of technology park as an instrument to promote innovation globally. Technology park must be able to collaborate with internationally-recognised institutions and industry. 
In order to improve knowledge transfer, companies must encourage their employees not only to learn but also to teach their colleagues. In this regard, incentives must be designed to promote in-plant training. Teaming with expatriates, for instance, stimulates the process of sharing of ideas, guidance, and experimentation. This effort is consistent with the theory of social exchange that emphasises the role of intrinsic rewards in motivating employees to share their experience, knowledge and insights with others of within or without. Employees may not want to contribute if they receive no rewards in return. Such behaviour has to do with economic exchange theory that individuals will behave according to rational self-interest (Bock \& Kim, 2002).

Previous studies agree that knowledge can be generated through the sharing of experience among people (Davenport \& Prusak, 1998; Leonard \& Sensiper, 1998). Sharing through mentoring, particularly, positively affects job satisfaction and retention because people are better understood and absorb knowledge from their mentors rapidly (Mullen \& Noe, 1999). Mentoring is also a way to ensure the transfer of skills from one personnel to another. When there is a transfer of skills, it saves the firm from being at a severe disadvantage when key employees quit because they take with them their expertise, as crucial technology competency is embedded in those personnel. When these people work for another firm, their knowledge will be beneficial to the new firm (Macdonald, 1992).

The findings of this study accentuate the importance of knowledge transfer from MNCs to the host country firm. Acknowledging the constraints particularly, human factor, absorptive capacity, competition for resources or ethical dilemmas and cultural barriers, strategies and mechanisms should be devised accordingly in order to assist $\mathrm{MNC}$ in their effort to improve knowledge transfer.

Funding: Authors would like to thank Universiti Sains Malaysia for funding this project under the Short-Term Research Grant Scheme No. 304/PJJAUH/6315270.

Competing Interests: The authors declare that they have no competing interests.

Acknowledgement: Both authors contributed equally to the conception and design of the study.

\section{REFERENCES}

Allison, P. (2009). Fixed effects regression models. In fixed effects regression models: SAGE Publications, Inc.

Araújo, B. C., Bogliacino, F., \& Vivarelli, M. (2009). The role of skill enhancing trade in Brazil: Some evidence from micro data. Economic Research Papers, 97(10), 1-22.

Ariff, M., Yokoyama, H., \& Kenkyūjo, A. K. (1992). Foreign direct investment in Malaysia: Trends, determinants and implications. Tokyo: Institute of Developing Economies.

Awang, A. H., Hussain, M. Y., \& Malek, J. A. (2009a). Promoting knowledge tansfer in sience and tchnology: A cse sudy of tchnology prk Malaysia. Croatian Economic Survey, 11(1), 95-113.

Awang, A. H., Hussain, M. Y., \& Malek, J. A. (2009b). Promoting knowledge transfer in science and technology: A case study of technology park Malaysia (TPM). Croatian Economic Survey(11), 95-113.

Badriah, L. S., Alisjahbana, A. S., Wibowo, K., \& Hadiyanto, F. (2019). The determinants of large and medium industrial sectors productivity growth in Indonesia. Economics Development Analysis Journal, 8(1), 94-107. Available at: https://doi.org/10.15294/edaj.v8i1.28827.

Ballot, G., Fakhfakh, F., \& Taymaz, E. (2001). Firms' human capital, R\&D and performance: A study on French and swedish firms. Labour Economics, 8(4), 443-462.

Bandick, R., \& Hansson, P. (2009). Inward FDI and demand for skills in manufacturing firms in Sweden. Review of World Economics, 145(1), 111-131. Available at: https://doi.org/10.1007/s10290-009-0002-9.

Bhatti, K. K., \& Qureshi, T. M. (2007). Impact of employee participation on job satisfaction, employee commitment and employee productivity. International Review of Business Research Papers, 3(2), 54-68.

Blomström, M., \& Kokko, A. (1998). Multinational corporations and spillovers. Journal of Economic surveys, 12(3), $247-277$. Available at: https://doi.org/10.1111/1467-6419.00056. 
Blomström, M., \& Persson, H. (1983). Foreign investment and spillover efficiency in an underdeveloped economy: Evidence from the Mexican manufacturing industry. World Development, 11(6), 493-501. Available at: https://doi.org/10.1016/0305$750 x(83) 90016-5$.

Blomström, M., \& Wolff, E. N. (1994). Multinational corporations and productivity convergence in Mexico. Convergence of productivity: Cross-national studies and historical evidence, 263-284.

Blonigen, B. A., \& Slaughter, M. J. (2001). Foreign-affiliate activity and US skill upgrading. Review of Economics and Statistics, 83(2), 362-376. Available at: https://doi.org/10.1162/00346530151143888.

Bock, G. W., \& Kim, Y.-G. (2002). Breaking the myths of rewards: An exploratory study of attitudes about knowledge sharing. Information Resources Management Journal, 15(2), 14-21. Available at: https://doi.org/10.4018/irmj.2002040102.

Böckerman, P., Ilmakunnas, P., \& Johansson, E. (2011). Job security and employee well-being: Evidence from matched survey and register data. Labour Economics, 18(4), 547-554. Available at: https://doi.org/10.1016/j.labeco.2010.12.011.

Boghean, C., \& State, M. (2015). The relation between foreign direct investments and labour productivity in the European union countries. Procedia Economics and Finance, 32, 278-285. Available at: https://doi.org/10.1016/s22 12-5671(15)01392-1.

Bronzini, R., \& Piselli, P. (2009). Determinants of long-run regional productivity with geographical spillovers: The role of R\&D, human capital and public infrastructure. Regional Science and Urban Economics, 39(2), 187-199. Available at: https://doi.org/10.1016/j.regsciurbeco.2008.07.002.

Bruno, G. S., Crinò, R., \& Falzoni, A. M. (2012). Foreign direct investment, trade, and skilled labour demand in eastern Europe. Labour, 26(4), 492-513. Available at: https://doi.org/10.1111/labr.12001.

Buckley, P. J., Clegg, J., \& Wang, C. (2002). The impact of inward FDI on the performance of Chinese manufacturing firms. Journal of International Business Studies, 33(4), 637-655. Available at: https://doi.org/10.1057/palgrave.jibs.8491037.

Bwalya, S. M. (2006). Foreign direct investment and technology spillovers: Evidence from panel data analysis of manufacturing firms in Zambia. Journal of Development Economics, 81(2), 514-526. Available at: https://doi.org/10.1016/j.jdeveco.2005.06.011.

Caves, R. E. (1971). International corporations: The industrial economics of foreign investment. Economica, 38(149), 1-27. Available at: https://doi.org/10.2307/2551748.

Chennells, L., \& Van Reenen, J. (1999). Has technology hurt less skilled workers? An econometric survey of the effects of technical change and the structure of pay and jobs. Working Paper No. W99/27 Institute for Fiscal Studies, London.

Coe, D. T., \& Helpman, E. (1995). International r\&d spillovers. European Economic Review, 39(5), 859-887.

Corvers, F. (1997). The impact of human capital on labour productivity in manufacturing sectors of the European Union. Applied Economics, 29(8), 975-987. Available at: https://doi.org/10.1080/000368497326372.

Davenport, T. H., \& Prusak, L. (1998). Working knowledge: How organizations manage what they know (pp. 649). Boston, Mass: Harvard Business School Press.

Driffield, N., Love, J. H., \& Taylor, K. (2009). Productivity and labour demand effects of inward and outward foreign direct investment on UK industry. The Manchester School, 77(2), 127-270.

Dunning, J. H., \& Rugman, A. M. (1985). The influence of hymer's dissertation on the theory of foreign direct investment. The American Economic Review, 75(2), 228-232.

Elia, S., Mariotti, I., \& Piscitello, L. (2009). The impact of outward FDI on the home country's labour demand and skill composition. International Business Review, 18(4), 357-372.

EPU. (2010). Tenth Malaysia plan 2010-2015. Putrajaya: Economic Planning Unit.

EPU. (2016). Eleventh Malaysia plan 2016-2020. Malaysia. Putrajaya: Economic Planning Unit.

EPU, \& World Bank. (2007a). Malaysia and the knowledge economy: Building a world-class higher education system. Malaysia: Economic Planning Unit.

EPU, \& World Bank. (2007b). Productivity and investment climate survey. Malaysia: Economic Planning Unit.

EPU, \& World Bank. (2010). Malaysia economic monitor. Growth through innovation. Malaysia: Economic Planning Unit, Putrajaya. 
Fagerberg, J. (2000). Technological progress, structural change and productivity growth: A comparative study. Structural Change and Economic Dynamics, 11 (4), 393-41 1. Available at: https://doi.org/10.1016/s0954-349x(00)00025-4.

Fan, X., \& Warr, P. G. (2000). Foreign investment, spillover effects and the technology gap: Evidence from China. Working Paper in Trade and Development No. 00/03, The Australian National University.

Figini, P., \& Görg, H. (1999). Multinational companies and wage inequality in the host country: The case of Ireland. Weltwirtschaftliches Archiv, 135(4), 594-612. Available at: https://doi.org/10.1007/BF02707386.

Foss, N. J., \& Pedersen, T. (2002). Transferring knowledge in MNCs: The role of sources of subsidiary knowledge and organizational context. Journal of International Management, 8(1), 49-67. Available at: https://doi.org/10.1016/s10754253(01)00054-0.

Frantzen, D. (2000). R\&D, human capital and international technology spillovers: A cross-country analysis. Scandinavian Journal of Economics, 102(1), 57-75. Available at: https://doi.org/10.1111/1467-9442.00184.

Girma, S., \& Görg, H. (2005). Foreign direct Investment, spillovers and absorptive capacity: Evidence from quantile regressions. Working Papers 1248, Kiel Institute for World Economics.

Girma, S., Greenaway, D., \& Wakelin, K. (2001). Who benefits from foreign direct investment in the UK? Scottish Journal of Political Economy, 48(2), 119-133. Available at: https://doi.org/10.1111/1467-9485.00189.

Giroud, A., \& Mirza, H. (2006). Factors determining supply linkages between transnational corporations and local suppliers in ASEAN. Transnational Corporations, 15(3), 1. Available at: https://doi.org/10.1111/sjpe.12023.

Hair, Joseph, F., Rolph, E. A., Ronald, L. T., \& William, C. B. (1995). Multivariate data analysis. London: Prentice Hall.

Hoboubi, N., Choobineh, A., Ghanavati, F. K., Keshavarzi, S., \& Hosseini, A. A. (2017). The impact of job stress and job satisfaction on workforce productivity in an Iranian petrochemical industry. Safety and Health at Work, 8(1), 67-71. Available at: https://doi.org/10.1016/j.shaw.2016.07.002.

Hollanders, H., \& Ter Weel, B. (2002). Technology, knowledge spillovers and changes in employment structure: Evidence from six OECD countries. Labour Economics, 9(5), 579-599.

Jaguli, A. R., Malek, M. M., \& Palil, M. R. (2014). Technology diffusion through production process and the innovative capacity of local suppliers. Jurnal Pengurusan, 42, 89 - 102. Available at: https://doi.org/10.17576/pengurusan-2014-42-08.

Kao, H., Kao, P.-H., \& Mazzuchi, T. A. (2006). Taiwanese executive practice knowledge management in mainland China and Southeast Asia Malaysia. VINE. Very Informal Nerwsletter on Library Automation, 36(3), 341-352. Available at: https://doi.org/10.1108/03055720610703605.

Keller, W. (1998). Are international R\&D spillovers trade-related?: Analyzing spillovers among randomly matched trade partners. European Economic Review, 42(8), 1469-1481.

Lall, S. (1978). Transnationals, domestic enterprises, and industrial structure in host LDCs: A survey. Oxford Economic, 30(2), 217-248. Available at: https://doi.org/10.1093/oxfordjournals.oep.a041410.

Leamer, E. (1994). Trade, wages and revolving door ideas. National Bureau of Economic Research Working Paper Series.

Lee, M. T., Mohayiddin, M. G., \& Kanesan, M. (2011). Soft technology transfer for Japanese MNCs in Malaysia: A conceptual model. Paper presented at the Proceedings of the International Lifelong Learning Conference (ICLLL), Kuala Lumpur.

Leonard, D., \& Sensiper, S. (1998). The role of tacit knowledge in group innovation. California Management Review, 40(3), $112-$ 132.

Liu, W. S., Agbola, F. W., \& Dzator, J. A. (2016). The impact of FDI spillover effects on total factor productivity in the Chinese electronic industry: A panel data analysis. Journal of the Asia Pacific Economy, 21(2), 217-234. Available at: https://doi.org/10.1080/13547860.2015.1137473.

Liu, X., Parker, D., Vaidya, K., \& Wei, Y. (2001). The impact of foreign direct investment on labour productivity in the Chinese electronics industry. International Business Review, 1O(4), 421-439. Available at: https://doi.org/10.1016/So9695931(01)00024-5.

Macdonald, S. (1992). Information networks and the exchange of information, in C. Antonelli (ed.), The Economics of Information Networks (pp. 51-69). North-Holland, Amsterdam. 
International Journal of Asian Social Science, 2020, 10(9): 593-611

Malaysia Investment Development Authority. (2018). MIDA annual report: Investment performance 2018. Malaysia: Kuala Lumpur. Malaysia Productivity Corporation. (2017). Productivity Report 2016/2017. Kuala Lumpur: Malaysia Productivity Corporation.

McMillan, M., \& Rodrik, D. (2011). Globalization, structural change and productivity growth. In making globalization socially sustainable (pp. 49-84): WTO.

Mebratie, A. D., \& Bedi, A. S. (2013). Foreign direct investment, black economic empowerment and labour productivity in South Africa. The Journal of International Trade \& Economic Development, 22(1), 103-128. Available at: https://doi.org/10.1080/09638199.2013.745287.

MIDA. (2018). MIDA annual report: Investment performance 2018. Malaysia: Malaysia Investment Development Authority, Kuala Lumpur.

Millán, J. M., Hessels, J., Thurik, R., \& Aguado, R. (2013). Determinants of job satisfaction: A European comparison of selfemployed and paid employees. Small Business Economics, 4O(3), 651-670. Available at: https://doi.org/10.1007/s111870 1 1-9380-1.

Mullen, E. J., \& Noe, R. A. (1999). The mentoring information exchange: When do mentors seek information from their protégés? Journal of Organizational Behavior: The International Journal of Industrial, Occupational and Organizational Psychology and Behavior, 20(2), 233-242. Available at: https://doi.org/10.1002/(sici)1099-1379(199903)20:2<233::aidjob925>3.0.co;2-f.

OECD. (2011). Review of innovation in Southeast Asia: Country profile of innovation in Malaysia. Malaysia: Organisation for Economic Co-operation and Development.

Slaughter, M. J. (2002). Does inward foreign direct investment contribute to skill upgrading in developing countries? Center for Economic Analysis Working Paper (2002-08).

Sulaiman, N., Azman, N. M., \& Ismail, R. (2016). The impact of globalization on labor productivity in the services sector. Jurnal Ekonomi Malaysia, 50(2), 71-81.

Taylor, K., \& Driffield, N. (2005). Wage inequality and the role of multinationals: Evidence from UK panel data. Labour Economics, 12(2), 223-249. Available at: https://doi.org/10.1016/j.labeco.2003.11.003

Wang, C.-C., Huang, M.-H., \& Chen, D.-Z. (2012). The evolution of knowledge spillover and company cluster in semiconductor industry. Journal of the Knowledge Economy, 3(2), 109-124. Available at: https://doi.org/10.1007/s13132-011-0080-5.

Yunus, N. M. (2017). Sheepskin effects in the returns to higher education: New evidence for Malaysia. Asian Academy of Management Journal, 22(1), 151-182. Available at: https://doi.org/10.21315/aamj2017.22.1.7.

Yunus, N. M., \& Hamid, F. S. (2017). Changing returns to education in the Malaysian electric \& electronic sector, $2002-2007$. International Journal of Economic Research, 14(16), 295-308.

Yunus, N. M., Said, R., \& Hook, L. (2014). Do cost of training, education level and R\&D investment matter towards influencing labour productivity. Jurnal Ekonomi Malaysia, 48(1), 133-142. Available at: https://doi.org/10.17576/jem-2014-480111.

Yunus, N. M., Said, R., \& Hook, L. S. (2014). Do cost of training, education level and R\&D investment matter towards influencing labour productivity. Jurnal Ekonomi Malaysia, 48(1), 133-142. Available at: https://doi.org/10.17576/jem2014-4801-11.

Yunus, N. M., \& Wahob, N. A. (2019). Returns from self-employment in Malaysia. Revista Publicando, 5(18), 60-74.

Yunus, N. M., Said, R., \& Azman-Saini, W. N. W. (2015). Spillover effects of FDI and trade on demand for skilled labour in Malaysian manufacturing industries. Asian Academy of Management Journal, 20(2), 1-27.

Yunus, N. M. (2014). Factors affecting labour productivity, skilled labour and return to education in Malaysia. Thesis: Universiti Putra Malaysia.

Yunus, N. M. (2018). Returns from higher education in Malaysia: Analysis of wage-employed and self-employed workers. International Journal of Economics and Management, 12(2), 703-719.

Zellner, A. (1962). An efficient method of estimating seemingly unrelated regressions and tests for aggregation bias. Journal of the American Statistical Association, 57, 348-368. Available at: https://doi.org/10.1080/0162 1459.1962.10480664. 
Zellner, A. (1963). Estimators for seemingly unrelated regression equations: Some exact finite sample results. Journal of the American Statistical Association, 58(304), 977-992. Available at: https://doi.org/10.1080/0162 1459.1963.10480681.

Appendix A: Summary Statistics

\begin{tabular}{|c|c|c|c|c|c|}
\hline Variables & $\mathbf{N}$ & Minimum & Maximum & Mean & Std. Deviation \\
\hline High Skilled Workers & 266 & 7.63 & 10.60 & 9.48 & 0.56 \\
\hline Medium Skilled Workers & 266 & 5.38 & 10.61 & 8.56 & 0.90 \\
\hline Low_skilled Workers & 266 & 3.46 & 11.01 & 4.97 & 1.33 \\
\hline \multicolumn{6}{|l|}{ Independent Variables } \\
\hline Capital_Labour Ratio & 266 & -7.56 & -0.92 & -2.97 & 1.31 \\
\hline \multicolumn{6}{|l|}{ FDI Technology Effects } \\
\hline Foreign Investment & 266 & 15.82 & 23.74 & 20.22 & 1.51 \\
\hline $\begin{array}{l}\text { Share of foreign Investment from total } \\
\text { Investment }\end{array}$ & 266 & 0.71 & 4.59 & 3.68 & 0.65 \\
\hline Number of foreign Firm establishment & 266 & 1.39 & 5.75 & 4.15 & 0.97 \\
\hline \multicolumn{6}{|l|}{ FDI Knowledge Effects } \\
\hline $\begin{array}{l}\text { Share of local employment in foreign firms } \\
\text { (EMP) }\end{array}$ & 266 & 6.61 & 10.86 & 9.25 & 0.90 \\
\hline \multicolumn{6}{|l|}{ quadratic effects $\left(\mathrm{EMP}^{2}\right)$} \\
\hline Training Cost & 266 & 7.17 & 11.87 & 9.48 & 0.96 \\
\hline $\mathrm{R} \& \mathrm{D}$ & 266 & 5.39 & 14.06 & 10.29 & 1.56 \\
\hline Firm Size & 266 & 11.10 & 17.47 & 12.87 & 1.28 \\
\hline Domestic Investment & 266 & 15.79 & 23.95 & 20.36 & 1.17 \\
\hline $\begin{array}{l}\text { Share of Domestic Investment from total } \\
\text { Investment }\end{array}$ & 266 & 0.43 & 4.58 & 3.82 & 0.67 \\
\hline
\end{tabular}

Source: Malaysia Department of Statistics,2000-2018. 
Appendix B: Correlation Matrix

\begin{tabular}{|c|c|c|c|c|c|c|c|c|c|}
\hline Variables & $\begin{array}{c}\text { Capital_- } \\
\text { Labour } \\
\text { Ratio }\end{array}$ & $\begin{array}{c}\text { Total } \\
\text { Foreign } \\
\text { Investment }\end{array}$ & $\begin{array}{l}\text { Number of } \\
\text { foreign Firm }\end{array}$ & $\begin{array}{c}\text { EMP } \\
\text { (knowledge) }\end{array}$ & $\begin{array}{c}\mathrm{EMP}^{2} \text { (quadratic } \\
\text { effects of FDI } \\
\text { knowledge) }\end{array}$ & $\begin{array}{c}\text { Domestic } \\
\text { Investment }\end{array}$ & Firm Size & Training & $\mathbf{R} \& \mathbf{D}$ \\
\hline Capital_Labour & 1.000 & $-0.317^{\text {*** }}$ & $0.373^{\text {*** }}$ & $0.369^{\text {*** }}$ & $0.339^{* * *}$ & $-0.283^{\text {*** }}$ & $-0.508^{* *}$ & $-0.317^{\text {*** }}$ & -0.057 \\
\hline Foreign Capital Investment- & $-0.052^{* *}$ & 1.000 & $0.232^{* *}$ & $0.318^{* *}$ & $0.322^{* *}$ & $-0.168^{* *}$ & $-0.171^{* *}$ & $0.447^{* *}$ & $0.398^{* * *}$ \\
\hline Number of foreign Firm & $0.373^{* *}$ & $-0.055^{*}$ & 1.000 & $0.711^{* *}$ & $0.700^{* *}$ & -0.085 & $-0.715^{* *}$ & $0.157^{*}$ & $0.293^{* *}$ \\
\hline EMP (FDI knowledge) & $0.369^{* *}$ & $0.053^{* *}$ & $0.711^{* *}$ & 1.000 & $0.697^{* * *}$ & -0.042 & $-0.657^{* *}$ & $0.194^{* *}$ & $0.378^{* *}$ \\
\hline $\begin{array}{l}\mathrm{EMP}^{2} \text { (quadratic effects of } \\
\text { FDI knowledge) }\end{array}$ & $0.339^{* *}$ & $0.078^{*}$ & $0.700^{* *}$ & $0.797^{* *}$ & 1.000 & -0.022 & $-0.626^{* *}$ & $0.22 \mathrm{O}^{* *}$ & $0.397^{* *}$ \\
\hline Domestic Investment & $-0.283^{* *}$ & $0.741^{\text {*** }}$ & -0.085 & -0.042 & -0.022 & 1.000 & $0.401^{\text {** }}$ & $0.455^{* *}$ & $0.398^{* * *}$ \\
\hline Firm Size & $-0.508^{* * *}$ & $0.364^{* *}$ & $-0.715^{* *}$ & $-0.657^{* * *}$ & $-0.626^{* *}$ & $0.401^{* * *}$ & 1.000 & $0.401^{* * *}$ & $0.193^{* *}$ \\
\hline Training & $-0.317^{* * *}$ & $0.447^{* *}$ & $0.157^{*}$ & $0.194^{* *}$ & $0.220^{* * *}$ & $0.455^{* *}$ & $0.401^{* *}$ & 1.000 & $0.706^{* * *}$ \\
\hline $\mathrm{R} \& \mathrm{D}$ & -0.057 & O.398** & $0.293^{* *}$ & $0.378^{* *}$ & $0.397^{* * *}$ & $0.398^{* * *}$ & $0.493^{* * *}$ & $0.706^{* * *}$ & 1.000 \\
\hline
\end{tabular}

*. Correlation is significant at the 0.01 level (2-tailed).

**. Correlation is significant at the 0.05 level (2-tailed) 